\title{
PIERWSZA ŁACIŃSKA TERMINOLOGIA TEOLOGII WCIELENIA U TERTULIANA
}

Omawiając łacińską terminologię opisującą tajemnicę wcielenia należy zaznaczyć jakie były źródła, $\mathrm{z}$ których czerpał Tertulian w formułowaniu łacińskich odpowiedników dość często używanych terminów greckich. Pierwszym i zasadniczym źródłem dla Afrykańczyka było z pewnością Pismo Święte, chociaż czasami odwołuje się również do swoich poprzedników, szczególnie zaś Ireneusza z Lyonu. I chociaż był on nowatorem we wprowadzaniu terminów teologicznych w języku łacińskim, to czeka nas tutaj pierwsza niespodzianka. W zachowanych jego dziełach termin techniczny incarnatio ${ }^{1}$ upowszechnio-

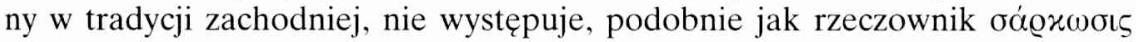
w Nowym Testamencie, w którym występują raczej formy opisowe, jak np.: Kai

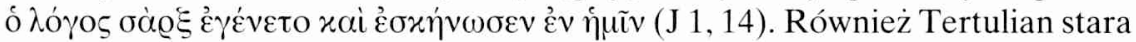
się opisać tę tajemnicę używając podobnych tj. opisowych form. Można je podzielić na kilka grup: formy opisujące ludzką naturę Chrystusa, Jego boskie pochodzenie, wydarzenie historyczne jako narodziny z Dziewicy Maryi, Jego wieczne istnienie w ciele oraz tajemnicę zbawienia w sensie globalnym. Jak zauważa B. Studer ${ }^{2}$, taka różnorodność wyrażeń i sposobów spojrzenia wskazuje na złożoność i centralizm tajemnicy wcielenia nie tylko u Tertuliana lecz w całej literaturze patrystycznej.

1. Dziełem, które w naszych poszukiwaniach najbardziej będzie pomocne jest De carne Christi, które w całości poświęcone zostało zwalczaniu różnych błędnych interpretacji tajemnicy wcielenia. Innymi dziełami, w których odnajdujemy wiele terminów dotyczących tego zagadnienia, są polemiczne utwory

${ }^{1}$ Teologia patrystyczna sformułowała pojęcie wcielenia idąc w ślad za wyrażeniami zaczerp-

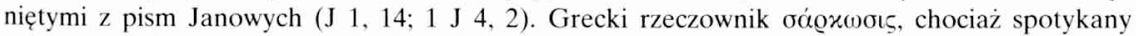
u Ireneusza (Adversus haereses III 18,3; 19,1) oraz Hipolita (Contra Noetum 16), upowszechnia się w tradycji Wschodu w IV wieku w kontekście herezji A polinarego, podobnie zresztą jak łaciński termin techniczny incarnatio; por. R. Braun, Deus Christianorum. Recherches sur le vocabulaire doctrinal de Tertullien, Paris 1977, 302.

${ }^{2}$ Por. B. Studer, Incarnazione, DPAC II 1771. 
Adversus Marcionem oraz Adversus Praxean. W tym pierwszym właśnie dziele

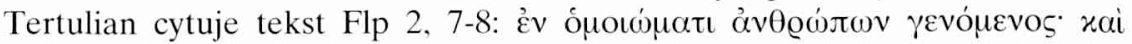

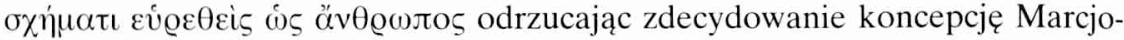
na o pozornym ciele Chrystusa w słowach:

„Plane de substantia Christi putant et hic marcionitae suffragari sibi apostolum, quod phantasma carnis fuerit in Christo, cum dicit quod in effigie Dei constitutus non rapinam existimavit pariari Deo, sed exhausit semetipsum accepta effigie serui, non veritate, et in similitudine hominis, non in homine, et figura inventus homo, non substantia, id est non carne.",3

Widoczne w tym tekście wyraźne podkreślenie przez Afrykańczyka prawdziwego człowieczeństwa w Chrystusie wskazuje pośrednio na fakt wcielenia.

W rodzącej się za jego czasów teologicznej literaturze w języku łacińskim Tertulian stosuje nowatorskie określenia Trójcy Osób (personae) w jedności istoty, które są widocznym śladem zdecydowanego przeciwstawienia się koncepcji dotyczącej relacji zachodzących między Ojcem a Synem, która to postrzegała w Bogu Ojcu całą istotę (tota substantia) boskości, a w Synu Bożym wyłącznie pochodzenie i część owej boskości ${ }^{4}$. Wcielenie jest u Afrykańczyka opisane jako zjednoczenie w jednej osobie dwóch natur (duae substantiae), boskiej i ludzkiej ${ }^{5}$. Spośród trzech terminów caro, corpus i homo Tertulian najchętniej używa tego pierwszego dla opisania ludzkiej natury Chrystusa. Podkreśla więc z całą stanowczością realność ciała Chrystusa retorycznie pytając:

„Porro, si caro eius negatur, quomodo mors eius adseveratur, quae propria carnis est passio, per mortem revertentis in terram, de qua est sumpta, secundum legem sui auctoris? Negata vero morte, dum caro negatur, nec de resurrectione constabit".

Zaznacza więc Afrykańczyk wyraźnie, iż odrzucając realność ludzkiej natury Chrystusa, zaprzecza się również Jego śmierci, która związana jest z ciałem, zanegowanie zaś śmierci prowadzi bezpośrednio do zanegowania zmartwychwstania, co z kolei stawia pod znakiem zapytania realność odkupienia. Tertulian idzie jeszcze dalej w swoim rozumowaniu: jeśli ciało jest pozorne, pozornym jest również duch, i jeśli ciało pozornie umarło, również duch „sine dubio phantasma discessit, cum spiritus, qui erat phantasma, discessit, et nusquam comparuit

${ }^{3}$ Adversus Marcionem V 20, 3, CCL 1, 724.

${ }^{4}$ Por. Adversus Praxean 8, 4, CCL 2, 1167.

5 Por. tamże, 27, 6, CCL 2, 1198; L. Bouyer, Syn Przedwieczny, tłum. W. Dzieża i P. Rak, Kraków 2000, 489n.

${ }^{6}$ Adversus Marcionem III 8, 6, CCL 1, 519; tamże, III 8, 4, CCL 1, 518: „Iam nunc, cum mendacium deprehenditur Christi caro, sequitur, ut et omnia, quae per carnem Christi gesta sunt, mendacio gesta sint, congressus contactus conuictus ipsae quoque virtutes". 
phantasma cum spiritu"7. W tym samym kontekście polemiki przeciwko przejawom doketów znajdujemy bardzo wyraźne sformułowanie Tertuliana „,confitentur vere corpus habuisse Christum". Użyty tutaj rzeczownik corpus zamiennie z rzeczownikiem caro zastosowany jest na określenie ludzkiego Ciała Chrystusa. Na oznaczenie ludzkiej natury Chrystusa i jego działalności na ziemi wśród ludzi stosuje Tertulian wyrażenie in carnem w odróżnieniu od jego natury ludzkiej, która przed wcieleniem nie była jeszcze objawiona, na której określenie używa wyrażenia ante carnem, czyli przed wcieleniem ${ }^{9}$. Dość często używa Afrykańczyk przymiotników carneus ${ }^{10}$, arnalis $^{11}$ i przysłówka carnaliter ${ }^{12}$,

${ }^{7}$ Tamże, IV 42, 7, CCL 1, 660: ,denique si caro non fuit, sed phantasma carnis, phantasma autem spiritus fuit, spiritus autem semetipsum expirauit et expirando discessit, sine dubio phantasma discessit, cum spiritus, qui erat phantasma, discessit, et nusquam comparuit phantasma cum spiritu"; thum. PSP 58, 329.

${ }^{8}$ De carne Christi 6, 3, CCL 2, 883.

${ }^{9}$ Por. Adversus Marcionem V 8, 4-5, CCL 1, 686: „Christum enim in floris figura ostendit, oriturum ex uirga profecta de radice Jesse, id est Virgine generis Dauid, filii Jesse, in quo Christo consistere haberet tota substantia spiritus, non quasi postea obventura illi, qui semper spiritus Dei fuerit, ante carnem quoque, - ne ex hoc argumenteris prophetiam ad eum Christum pertinere, qui ut homo tantum ex solo censu Dauid postea consecuturus sit Dei sui spiritum, - sed quoniam exinde, quo floruisset in carne sumpta ex stirpe Dauid, requiescere in illo haberet omnis operatio gratiae spiritalis et concessare et finem facere, quantum ad Iudaeos; sicut et res ipsa testatur, nihil exinde spirante penes illos spiritu creatoris, ablato a Iudaea sapiente et prudente architecto et consiliario et propheta, ut hoc sit: lex et prophetae usque ad Iohannem"; zob. Adversus Praxean 15,5, CCL 2, 1179: „Sermo enim vitae caro factus, et auditus et visus et contrectatus quia caro, qui ante carnem sermo tantum, in primordio apud Deum Patrem, non Pater apud semetipsum”.

${ }^{10}$ De carne 4, 6, CCL 2, 879: „Quaere ergo, de quibus dixerit, etsi praesumpseris invenisse: num erit tam stultum quam credere in Deum natum, et quidem ex Virgine, et quidem carneum, qui per illas naturae contumelias uolutatus sit?”; tamże, 5, 7, CCL 2, 881: „Ita utriusque substantiae census hominem et Deum exhibuit, hinc natum, inde non natum, hinc carneum, inde spiritalem, hinc infirmum, inde praefortem, hinc morientem, inde viventem”; tamże, 10, 1-2, CCL 2, 893: „Si, ut animam salvam faceret, in semetipso suscepit animam Christus, quia salva non esset nisi per ipsum, dum in ipso, non video, cur eam carnem fecerit animalem induendo carnem, quasi aliter animam saluam facere non posset, nisi carneam factam. Cum enim nostras animas non tantum non carneas, sed etiam a carne disiunctas salvas praestet, quanto magis illam, quam ipse suscepit, etiam non carneam redigere potuit in salutem?"

${ }^{11}$ Por. Adversus Marcionem III 18, 3, CCL 1, 532: „Ioseph, et ipse Christum figuraturus, vel hoc solo, ne demorer cursum, quod persecutionem a fratribus passus est ob dei gratiam, sicut et Christus a Iudaeis carnaliter $<$ fratribus $>$, cum benedicitur a patre etiam in haec verba: tauri decor eius, cornua unicornis cornua eius, in eis nationes ventilabit pariter ad summum usque terrae, non utique rhinoceros destinabatur unicornis nec minotaurus bicornis, sed Christus in illo significabatur, taurus ob utramque dispositionem, aliis ferus ut iudex, aliis mansuetus ut saluator, cuius cornua essent crucis extima”; De carne 22, 1, CCL 2, 912: „Ipse inprimis Mathaeus, fidelissimus euangelii commentator, ut comes domini, non aliam ob causam, quam ut nos originis Christi carnalis compotes faceret, ita exorsus est: liber generaturae Iesu Christi, filii Dauid, filii Abrahae" (Matth. 20, 30).

12 Por. Adversus Judaeos 10, 6, CCL 2, 1376: „Ioseph et ipsum Christum figurat uel hoc solo, ne cursum demorer, quod persecutionem a fratribus passus est et venumdatus in Aegyptum ob Dei 
które są zastosowane w odniesieniu do wcielenia ${ }^{13}$. Widać tutaj wyraźnie zarysowany związek przyczynowo-skutkowy występujący pomiędzy poszczególnymi fazami dzieła Zbawienia: wcielenie - według Tertuliana - jest bezsprzecznie fundamentem dzieła odkupienia i trzeba zdecydowanie podkreślić, że nie ma rzeczywistego i skutecznego odkupienia bez rzeczywistego wcielenia Syna Bożego.

Należy też podkreślić, iż wcielenie preegzystującego Słowa w konfrontacji ze zmartwychwstaniem ciał bardzo wcześnie zostało zauważone i poddane dyskusji w środowiskach elit intelektualnych chrześcijaństwa. Pierwsze wzmianki, jak widać w poprzednich artykułach, posiadamy już u Ignacego z Antiochii i u Justyna Męczennika, który zwrócił uwagę na 2. paruzje, do czego później wrócił Tertulian podkreślając, iż pierwsze przyjście Mesjasza dokonało się in humilitate, drugie zaś będzie przybyciem in gloria. Afrykańczyk wraz ze św. Ireneuszem podkreślił więc w nurcie polemiki antygnostyckiej prawdę o zbawieniu całego człowieka salus carnis właśnie poprzez wiarę w prawdziwe wcielenie Syna Bożego ${ }^{14}$. W tym kontekście wcielenie jawi się jako stan śmierci i zmartwychwstania ${ }^{15}$ i jako fundament nowych narodzin dla chrześcijan ${ }^{16}$. Tak pojęty realizm wcielenia stanowić będzie później konieczną przesłankę dla teologii ofiary jedynego Zbawiciela świata. W tej samej perspektywie całe życie chrześcijańskie, nie tylko jego początek w sakramencie chrztu św. i koniec w zmartwychwstaniu, jest widziane jako wierne naśladowanie wcielenia Syna Bożego ${ }^{17}$.

Rzeczownik corpus jest synonimem ${ }^{18}$ rzeczownika caro $^{19}$ stosowanym na oznaczenie ciała, podobnie jak jego derywaty corporalis, corporaliter, corpu-

gratiam, sicut et Christus ab Israel, a carnaliter fratribus, venumdatur, a Iuda cum traditur"; De carne 20, 7, CCL 2, 910: „Quid fuerit nouitatis in Christo ex Virgine nascenti, palam est, solum hoc scilicet, quod ex Virgine secundum rationem quam edidimus et ***, uti Virgo est et regeneratio nostra spiritaliter, ab omnibus inquinamentis sanctificata per Christum, Virginem et ipsum, etiam carnaliter, ut ex Virginis carne”.

13 Por. Braun, Deus Christianorum, dz. cyt., 303.

14 Por. B. Studer, Soteriologie der Kirchenväter, Freiburg 1978, 73nn.

15 Por. De carne 6, 6, CCL 2, 884.

${ }_{16}$ Por. tamże, 17, 1, CCL 2, 903-904: „Sed remisso Alexandro cum suis syllogismis, quos in argumentationibus torquet, etiam cum psalmis Valentini, quos magna impudentia quasi idonei alicuius auctoris interserit, ad unam iam lineam congressionem dirigamus: an carnem Christus ex Virgine acceperit, ut hoc praecipue modo humanam eam constet, si ex humana matrice substantiam traxit, quamquam licuit iam et de nomine hominis et de statu qualitatis et de sensu tractationis et de exitu passionis humanum constitisse".

${ }^{17}$ Por. S. Lyonnet, Sin. Redemption and Sacrifice, Roma 1970, 196.

18 Por. np. Adversus Marcionem V 4, 15, CCL 1, 675: „Cum vero adicit stigmata Christi in corpore suo gestare se - utique corporalia compedum - iam non putativam, sed veram et solidam carnem professus est Christi, cuius stigmata corporalia ostendit".

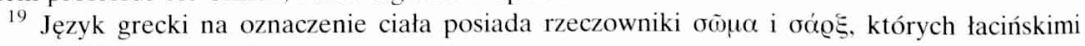
odpowiednikami są caro i corpus. 
lentia przez Tertuliana często są używane w odniesieniu do ludzkiej natury Chrystusa o czym świadczyć może następujący cytat z polemiki przeciwko Marcjonowi: „Si et mentitum alicubi dicis creatorem, longe maius mendacium est in tuo Christo, cuius corpus non fuit verum"20. A wyrażenie corpus Christi jest równoważne wyrażeniu caro Christi, które znajduje swoje zastosowanie na podkreślenie ludzkiej natury Syna Bożego, pośrednio zaś mówi o Jego wcieleniu, dzięki któremu objawił się ludzkości w ciele. Corpus Christi u Tertuliana często znajduje swoje zastosowanie do Eucharystii ${ }^{21}$ lub Kościoła ${ }^{22}$, podczas gdy caro Christi przeważnie zastosowane jest w odniesieniu do ciała ludzkiego Chrystusa. Wierny tendencji filozoficznej stoików Afrykańczyk sugeruje, iż wszystko co istnieje jest cielesne: „omne quod est, corpus est sui generis; nihil est incorporale nisi quod non est" ${ }^{\prime 23}$. W konsekwencji więc Bóg jest cielesny ${ }^{24}$ tak jak Logos ${ }^{25}$ i Duch Święty, cielesna jest także dusza ludzka ${ }^{26}$. Odrzucając więc interpretacje nasycone doketyzmem gnostyków tym wieloznacznym terminem Tertulian określa również naturę ludzką Chrystusa. Czasami Afrykańczyk w tym samym zdaniu łączy caro z derywatami corpus jak np. corporari, czego znamiennym świadectwem jest cytat:

„Sed ideo, inquis, nego Deum in hominem vere conversum ita ut et nasceretur et carne corporaretur, quia qui sine fine est etiam inconvertibilis sit necesse est"27.

${ }^{20}$ Adversus Marcionem II 28, 2, CCL 1, 508; tamże, IV 10, 16, CCL 1, 565: „Si natus ex homine est, ut filius hominis, corpus ex corpore est".

${ }^{21}$ Por. Adversus Marcionem III 19, 4, CCL 1, 533: „Sic enim Dominus in evangelio quoque vestro revelauit, panem corpus suum appellans, ut et hinc iam eum intellegas corporis sui figuram pani dedisse, cuius retro corpus in panem prophetes figuravit, ipso Domino hoc sacramentum postea interpretaturo”; tamze, IV 40, 3, CCL 1, 656: „Cur autem panem corpus suum appellat et non magis peponem, quem Marcion cordis loco habuit, non intellegens ueterem fuisse istam figuram corporis Christi dicentis per Hieremiam: aduersus me cogitauerunt cogitatum dicentes: venite, coiciamus lignum in panem eius, scilicet crucem in corpus eius?"; tamże, V 8, 3, CCL 1, 686: „Proinde panis et calicis sacramento iam in evangelio probavimus corporis et sanguinis dominici veritatem aduersus phantasma Marcionis, sed et omnem iudicii mentionem creatori competere, ut Deo iudici, toto paene opere tractatum est".

${ }^{22}$ Por tamże, V 19, 6, CCL 1, 722: Sicubi autem et ecclesiam corpus Christi dicit esse - ut hic ait adimplere se reliqua pressurarum Christi in carne pro corpore eius, quod est ecclesia -, non propterea et in totum mentionem corporis transferens a substantia carnis”; tamże: „Nam et supra reconciliari nos ait in corpore eius per mortem, utique in eo corpore, in quo mori potuit, per carnem mortuus et non per ecclesiam, plane propter ecclesiam corpus commutando pro corpore, carnale pro spiritali".

${ }^{23}$ De carne 11, 4, CCL 2, 895.

${ }^{24}$ Por. Adversus Praxean 7, 8, CCL 2, 1166-1167: „Quis enim negabit Deum corpus esse, etsi Deus spiritus est? Spiritus enim corpus sui generis in sua effigie”.

${ }^{25}$ Por. tamże, 8, 4, CCL 2, 1167: „Sermo autem Spiritu structus est et, ut ita dixerim, sermonis corpus est Spiritus".

${ }^{26}$ Por. De anima 5, 3, CCL 2, 787: „Quo, inquit, digresso animal emoritur, corpus est; consito autem spiritu digresso animal emoritur, ergo consitus spiritus corpus est; ergo corpus est anima".

27 De carne 3, 4, CCL 2, 876. 
Fakt wcielenia podkreślony jest również poprzez użycie terminu homo i filius hominis w stosunku do Chrystusa. Typowym przykładem tego może być zdanie”: „Deus homo natus est”28. Tak jak rzeczownikowi caro towarzyszy u Tertuliana czasownik induere, exhibere, gerere, znaleźć możemy przykłady zastosowania takiego wyrażenia jak homo eius co należy rozumieć jako składnik ludzki Chrystusa czy też człowiek Chrystus, dosłownie zaś człowiek Chrystusa $^{29}$. Czasami też dla podkreślenia tej prawdy używa Afrykańczyk wyrażeń takich jak: forma humana czy habitus humanus ${ }^{30}$. Przykładem takiego zastosowania jest tekst:
„Nec poteritis eum Iosedech filium dicere, qui nulla omnino ueste sordida, sed semper sacerdotali fuit exornatus nec umquam sacerdotali munere priuatus, sed Iesus iste Christus Dei Patris summus sacerdos, qui primo adventu suo humanae formae et passibilis venit in humilitate usque ad passionem, ipse effectus etiam hostia per omnia <aeua> pro omnibus nobis, qui post resurrectionem suam indu- tus podere 'sacerdos in aeternum' Dei Patris nuncupatur" 31 .

Łacińskim odpowiednikiem znanego wyrażenia Syn Człowieczy (ó viòs toṽ

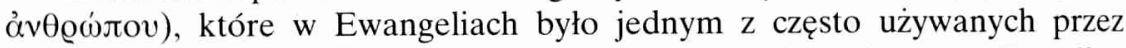
samego Chrystusa tytułów mesjańskich, był zwrot filius hominis. Tertulian umiejscawia się razem z Justynem i Ireneuszem w tym nurcie doktrynalnym, tak bardzo podkreślającym ludzką naturę Jezusa. Najbardziej trafnym cytatem może być fragment traktatu Przeciwko Prakseaszowi:

„Hunc missum a patre in Virginem et ex ea natum, hominem et Deum, filium hominis et filium Dei et cognominatum Iesum Christum" ${ }^{32}$.

Wspomnieliśmy już wcześniej, iż obok tych wyrażeń podkreślających w bezpośredni sposób prawdziwą naturę ludzką Chrystusa, czego podtekstem najprawdopodobniej była ostra polemika przeciwko tym nurtom heterodoksyjnym, które odwoływały się do doketyzmu jako teorii wyjaśniającej relację Boga Ojca do Syna, który dał się ludziom poznać w ludzkim ciele. Tertulian stosuje jeszcze wiele innych zwrotów przenośnych czy też bardziej opisowych wskazu-

${ }^{28}$ Adversus Marcionem IV 13, 6, CCL 1, 573.

${ }^{29}$ Np. De carne 5, 7, CCL 2, 881-882; Adversus Marcionem III 6, 10, CCL 1, 516; por. Braun, Deus Christianorum, dz. cyt., 308; R. Cantalamessa, Cristologia di Tertulliano, Freiburg 1962, 186-189.

${ }^{30}$ Por. Adversus Marcionem II 16, 3, CCL 1, 493: „Qui credimus deum etiam in terris egisse et humani habitus humilitatem suscepisse ex causa humanae salutis, longe sumus a sententia eorum, qui nolunt Deum curare quicquam".

${ }^{31}$ Adversus Judaeos 14, 8, CCL 2, 1393-1394.

32 Adversus Praxean 2, 1, CCL 2, 1160; tamże, 21, 12, CCL 2, 1188: „Sicut enim pater habet vitam aeternam a semetipso, ita et filio dedit uitam aeternam habere in semetipso et iudicium dedit illi facere in potestate; quia filius hominis est, per carnem scilicet, sicut et filius Dei per spiritum eius”; por. C. Colpe, Der Begriff Menschensohn und die Methode der Erforschung messianischer Prototypen, „Kairos” 11 (1969) 241-260. 
jąc również na zjednoczenie dwóch natur w Chrystusie. Do tego typu wyrażeń należą carnem fieri ${ }^{33}$ albo też in carne fieri znajdujemy zwrot induere (w różnych formach) carnem lub hominem ${ }^{34}$, carnem accipere ${ }^{35}$, carnem sumere, humani habitum suscipere ${ }^{36}$, carnem subire $^{37}$, które to wyrażenie w IV wieku zostanie zastąpione wyrażeniem adsumere carnem lub też hominem, a które Tertulian w swoich utworach zdaje się ignorować. Na określenie tajemnicy wcielenia Afrykańczyk używa również zwrotu gestare carnem ${ }^{38}$ lub też hominem gestare ${ }^{39}$ oraz circumferre carnem $^{40}$, co koresponduje z greckim wyrażeniem $\sigma \alpha \varrho x o \phi o ́ \varrho \varepsilon ı v$. Naturę Boską i ludzką w osobie Jezusa Chrystusa podkreśla fragment traktatu Przeciw Prakseaszowi:

„Cum quibus enim faciebat hominem et quibus faciebat similem, filio quidem qui erat induiturus hominem, spiritu vero qui erat sanctificaturus hominem, quasi cum ministris et arbitris ex unitate trinitatis loquebatur" ${ }^{\prime 4}$.

Czasami podkreślając naturę ludzką Chrystusa w duchu spełnionych proroctw Starego Testamentu, Tertulian posługuje się tytułami mesjańskimi, jak filius David i filius Abrahae ${ }^{42}$.

${ }^{33}$ Por. Adversus Praxean 27, 6, CCL 2, 1199: ,Igitur sermo in carne; tum et de hoc quaerendum quomodo sermo caro sit factus, utrumne quasi transfiguratus in carne an indutus carnem".

${ }^{34}$ Por. Adversus Marcionem III 7, 6, CCL 1, 517: „Sic et apud Zachariam in persona Iesu, immo et in ipso nominis sacramento, verus summus sacerdos patris, Christus Iesus, duplici habitu in duos aduentus deliniatur, primo sordidis indutus, id est carnis passibilis et mortalis indignitate, cum et diabolus aduersabatur ei, auctor scilicet iudae traditoris, ne dicam etiam post baptisma temptator, dehinc despoliatus pristinas sordes et exornatus podere et mitra et cidari munda, id est secundi adventus gloria et honore".

35 De carne 6, 5, CCL 2, 884: „Si numquam eiusmodi causa angelorum corporandorum, habes, cur non nascendo acceperint carnem".

${ }^{36}$ Por. Adversus Marcionem II 16, 3, CCL 1, 493: ,humani habitus humilitatem suscepisse ex causa humanae salutis".

${ }^{37}$ Por. De carne 11, 1, CCL 2, 894: „Sed aliam argumentationem eorum conuenimus, exigentes, cur animalem carnem subeundo Christus animam carnalem habuisse videatur”.

${ }^{38}$ Por. De carne 5, 9, CCL 2, 882: „Et in semetipsum quidem ut carnem gestarit sine ossibus duram, sine musculis solidam, sine sanguine cruentam, sine tunica vestitam, sine fame esurientem, sine dentibus edentem, sine lingua loquentem, ut phantasma auribus fuerit sermo eius per imaginem vocis: fuit itaque phantasma etiam post resurrectionem, cum manus et pedes suos discipulis inspiciendos offert adspicite, dicens, quod ego sum, quia spiritus ossa non habet, sicut me habentem videtis?"

39 Por. tamże 14, 1, CCL 2, 899: „Ut hominem gestaret Christus, salus hominis fuit causa, scilicet id restituendum quod perierat: homo perierat, hominem restitui oportuerat - ut angelum gestaret Christus, nihil tale".

${ }^{40}$ Por. Adversus Marcionem III 11, 2, CCL 1, 522.

${ }^{41}$ Adversus Praxean 12, 3, CCL 2, 1173.

42 Por. De carne 22, 1, CCL 2, 912: „Ipse inprimis Mathaeus, fidelissimus euangelii commentator, ut comes Domini, non aliam ob causam, quam ut nos originis Christi carnalis compotes faceret, ita exorsus est: liber generaturae Iesu Christi, filii Dauid, filii Abrahae”. 
2. Terminami opisującymi boską naturę Chrystusa w pismach Tertuliana są: filius Dei, Dei Verbum, induere carnem, duplex status. W tym kontekście bardzo znamienny jest następujący fragment: „Ita cum ipse de Spiritu Dei spiritus Deus est, ex Deo natus, ipse et ex carne hominis <caro> est homo, in carne generatus" ${ }^{\text {43 }}$. Czasami Afrykańczyk dla podkreślenia prawdy o dwóch naturach Boskiej i ludzkiej w Chrystusie posługuje się wyrażeniem homo Deo mixtus $^{44}$, które jest echem współczesnego Tertulianowi nauczania katechetycznego ${ }^{45}$, jakkolwiek ze względu na wieloznaczność czasownika miscere, wyrażenie to może przysparzać wielu trudności interpretacyjnych. Wcielenie bowiem nie dokonało się poprzez zmieszanie dwóch natur tworząc jakąś odrębną trzecią rzeczywistość, w przeciwnym wypadku Słowo przestałoby być prawdziwym Bogiem, a przyjęte przez Chrystusa ciało ludzkie nie miałoby wszystkich cech charakteryzujących prawdziwego człowieka ${ }^{46}$. Autor bardzo wyraźnie podkreśla, iż pomimo dwóch natur, Chrystus jest jedną osobą, o czym doskonale świadczy następujący fragment:

„Videmus duplicem statum, non confusum sed coniunctum in una persona, Deum et hominem Iesum - de Christo autem differo - et adeo salva est utriusque proprietas substantiae, ut et spiritus res suas egerit in illo, id est virtutes et opera et signa, et caro passiones suas functa sit, esuriens sub diabolo, sitiens sub samaritide, flens Lazarum, anxia usque ad mortem, denique et mortua [est] ${ }^{, 47}$.

Przytoczony fragment bardzo przypomina definicję Soboru Chalcedońskiego o dwóch niezmieszanych ze sobą naturach w Chrystusie. Pod tym względem Tertulian wydaje się być prekursorem tych rozwiązań terminologicznych, które upowszechniły się w Kościele znacznie później, chociaż trudno jest udowodnić, iż Augustyn używając formuły duplex status in una persona odwołuje się do sławnego Afrykańczyka z początków III wieku ${ }^{48}$.

43 De carne 18, 7, CCL 2, 907.

44 Por. Apologeticum 21, 14, CCL 1, 125: „Iste igitur dei radius, ut retro semper praedicabatur, delapsus in Virginem quandam et in utero eius caro figuratus nascitur homo Deo mixtus"; por. Adversus Marcionem II 27, 6, CCL 1, 506-507: ,Igitur quaecumque exigitis Deo digna, habebuntur in Patre invisibili incongressibilique et placido et, ut ita dixerim, philosophorum Deo, quaecumque autem ut indigna reprehenditis, deputabuntur in filio et viso et audito et congresso, arbitro Patris et ministro, miscente in semetipso hominem et Deum, in virtutibus deum, in pusillitatibus hominem, ut tantum homini conferat quantum Deo detrahit".

45 Por. Braun, Deus Christianorum, dz. cyt., 313.

46 Por. B. Studer, Dio Salvatore nei Padri della Chiesa, Roma 1986, 106.

47 Adversus Praxean 27, 11, CCL 2, 1199-1200; por. tamże, 27, 1, CCL 2, 1198 : ,undique enim obducti distinctione patris et filii quam manente coniunctione disponimus ut solis et radii et fontis et fluvii, per individuum tamen numerum duorum et trium, aliter eam ad suam nihilominus sententiam interpretari, conantur ut aeque in una persona utrumque distinguant, patrem et filium, dicentes filium carnem esse, id est hominem, id est Iesum, patrem autem spiritum, id est Deum, id est Christum". 
Omawiając Boską naturę Chrystusa należy zaznaczyć, iż Tertulian wraz z takimi teologami, jak św. Justyn, św. Ireneusz, Orygenes i Nowacjan prezentuje pewną tendencję subordynacjanistyczną, o czym świadczyć może taki oto tekst: „Pater enim tota substantia est, filius uero derivatio totius et portio sicut ipse profitetur: quia Pater maior me est" ${ }^{49}$. Według tej koncepcji Chrystus jako Syn Boży jest podporządkowany Ojcu. Punktem wyjścia do sformułowania takiego poglądu w teologii były teksty J 14, 28 oraz Mk 10, 18; 13, 32, które w ówczesnym okresie interpretowano dosłownie ${ }^{50}$.

Najmniej wątpliwości interpretacyjnych nastręczają takie wyrażenia, jak Dei filius ${ }^{51}$, Verbum $^{52}$ lub Sermo Dei ${ }^{53}$, których dość często używa Tertulian dla podkreślenia Boskiej godności Chrystusa. Prawdą jest, iż te dwa ostatnie określenia czasami odnoszą się do natchnionego słowa Bożego zanotowanego w Piśmie Świętym, lecz czasem mogą być zastosowane w odniesieniu do Chrystusa Syna Bożego. Spotkać można również zwrot transfiguratio substantiae, który zastosowany jest do Syna Bożego ${ }^{54}$. Te ostanie wyrażenia podkreślają pozytywny opis jaki stosuje Tertulian w stosunku do tajemnicy wcielenia. $\mathrm{Na}$ tej podstawie można powiedzieć, iż w Chrystusie współistnieją i współdziałają dwie odrębne natury, z których każda zachowuje swoje właściwości ${ }^{55}$.

3. Trzecią grupą terminów są wyrażenia określające narodziny Chrystusa z Dziewicy Maryi. Pamiętać trzeba, iż Tertulian podkreślał dziewictwo Maryi

${ }^{48}$ Por. A. Grillmeier, Gesù il Cristo nella fede della Chiesa, I, Dall'età apostolica al Concilio di Calcedonia (451), Brescia 1982, 318-330.

49 Adversus Praxean 9, 2, CCL 2, 1168.

${ }^{50}$ Por. W. Marcus, Der Subordinationismus als Historisches Phänomen, München 1943, 31nn; M. Simonetti, Subordinazionismo, DPAC 3327.

${ }^{51}$ Por. De praescriptione 20,1, CCL 1, 201: „Christus Iesus Dominus noster, permittat dicere interim, quisquis est, cuiuscumque dei filius, cuiuscumque materiae homo et Deus, cuiuscumque fidei praeceptor, cuiuscumque mercedis repromissor, quid esset, quid fuisset, quam patris voluntatem administraret, quid homini agendum determinaret, quamdiu in terris agebat, ipse pronuntiabat siue populo palam, siue discentibus seorsum, ex quibus duodecim praecipuos lateri suo allegerat destinatos nationibus magistros".

52 Por. De carne 19, 2, CCL 2, 907: „Adeo singulariter, ut de domino, scriptum est: sed ex Deo natus est; merito, qua Verbum Dei, [et cum Dei Verbo spiritus, et in spiritu dei virtus et quicquid dei est Christus], qua caro autem non ex sanguine nec ex carnis et viri voluntate, quia ex dei voluntate Verbum caro factum est".

${ }^{53}$ Por. De oratione 1, 2, CCL 1, 257: „Omnia de carnalibus in spiritalia renovavit noua dei gratia superducto euangelio, expunctore totius retro vetustatis, in quo et dei spiritus et Dei sermo et Dei ratio approbatus est Dominus noster Iesus Christus, spiritus, quo valuit, sermo, quo docuit, ratio, quo venit".

${ }^{54}$ Por. Adversus Praxean 27, 8, CCL 2, 1199: „Si enim sermo ex transfiguratione et demutatione substantiae caro factus est, una iam erit substantia Iesus ex duabus, ex carne et spiritu, mixtura quaedam ut electrum, ex auro et argento, et incipit nec aurum esse, id est spiritus, neque argentum, id est caro, cum alterum altero mutatur et tertium quid efficitur".

55 Por. Studer, Dio Salvatore nei Padri della Chiesa, dz. cyt., 107. 
ante partum, lecz odmawiał jej utrzymanie tego przywileju dziewictwa in partu i post partum $^{56}$. Afrykańczyk bardzo często mówi o tajemnicy wcielenia podkreślając wszystkie trzy elementy, używa zarówno zwrotów jasno świadczących o Synostwie Bożym ${ }^{57}$, jak narodzeniu z Dziewicy i jego prawdziwym człowieczeństwie $^{58}$. Innymi wyrażeniami podkreślającymi fakt, iż Chrystus został poczęty i zrodzony z Maryi są: conceptus et partus de (ex) Virgine Maria ${ }^{59}$, generare, generatus ${ }^{60}$ (genitus $^{61}$ ). Znaleźć możemy również całą grupę terminów zastosowanych na opisanie faktu narodzin. Należą do nich nasci, nativus, nativitas. Terminy te jednak mogą być wieloznaczne, jak np. przymiotnik nativus u Tertuliana może odnosić się do narodzin ziemskich człowieka i w jakiś sposób stać w opozycji do takich pojęć, jak perpetuitas, aeternitas, divinitas i zbliżać się znaczeniowo do pojęcia mortalitas ${ }^{62}$. Precyzując zastosowanie tego rzeczownika na określenie wcielenia, dość często dodaje Afrykańczyk dopełniacz Chris$t i^{63}$. To poszukiwanie terminów technicznych dla opisania tajemnicy wcielenia przez Tertuliana wymaga pewnego wyjaśnienia, które dotyczy podwójnych narodzin Chrystusa, pierwsze $\mathrm{z}$ nich dokonało się z Boga Ojca, a drugie z Maryi Dziewicy. Substantia oznacza bowiem uczestnictwo w początkowej substancji, czyli naturze, co później zostanie zdefiniowane jako homoou$\operatorname{sios}^{64}$. Tertulian nie rozróżniał po prostu dwóch natur przypisując w konsekwencji cierpienie i mękę tylko dla jednej, lecz cała jego chrystologia rozróżnienia rozciąga się również na rozróżnienie podwójnej woli; woli Ojca i woli Chrystusa. Według Afrykańczyka należy odróżnić wolę Ojca, który chciał

${ }^{56}$ Por. De monogamia 8, 2, CCL 2, 1239; De virginibus velandis 6, 3, CCL 2, 1216; De carne Christi 24.

${ }^{57}$ Por. De carne 5, 6, CCL 2, 881: „Haud aliter non dicetur homo Christus sine carne nec hominis filius sine aliquo parente homine, sicut nec Deus sine spiritu dei nec Dei filius sine Deo Patre".

58 Por. tamże, 20, 7, CCL 2, 910: „Quid fuerit novitatis in Christo ex Virgine nascenti, palam est, solum hoc scilicet, quod ex Virgine secundum rationem quam edidimus et ***, uti Virgo est et regeneratio nostra spiritaliter, ab omnibus inquinamentis sanctificata per Christum, Virginem et ipsum, etiam carnaliter, ut ex Virginis carne".

${ }^{59}$ Por. tamże, 23, 2, CCL 2, 914: „Agnoscimus ergo signum contradicibile conceptum et partum Virginis Mariae, de quo academici isti: 'peperit et non peperit, Virgo et non Virgo'; quasi non, et si ita esset dicendum, a nobis magis dici conveniret".

${ }^{60}$ Por. tamże, 18, 7, CCL 2, 907: „Ita cum ipse de spiritu dei spiritus Deus est, ex Deo natus, ipse et ex carne hominis <caro> est homo, in carne generatus".

${ }^{61}$ Por. Adversus Praxean 7, 1, CCL 2, 1165: „Conditus ab eo primum ad cogitatum in nomine sophiae - Dominus condidit me initium viarum -, dehinc generatus ad effectum - cum pararet caelum, aderam illi -, exinde eum Patrem sibi faciens de quo procedendo filius, factus est primogenitus ut ante omnia genitus et unigenitus, ut solus ex deo genitus, proprie de vulua cordis ipsius secundum quod et Pater ipse testatur: eructauit cor meum sermonem optimum".

${ }^{62}$ Por. Adversus Valentinianos 11, 4, CCL 2, 763; De anima 24, 2, CCL 2, 816; Braun, Deus Christianorum, dz. cyt., 319.

${ }^{63}$ Np. De carne 23, 1, CCL 2, 914.

${ }^{64}$ Por. B. Studer, Consubstantialis Patri - consubstantialis matri, REA 18 (1972) 85-115. 
śmierci Chrystusa z powodu naszych grzechów, i wolę Chrystusa, który we wszystkim był posłuszny Ojcu. Myśl taka zostaje sformułowana na podstawie egzegezy Tertuliana Ps 21,2 , zacytowanego w Mt 27, $48^{65}$, chociaż nie można tu jeszcze mówić o dwóch wolach (Boskiej i ludzkiej) w Chrystusie.

W kontekście polemiki z judaizmem Tertulian posługuje się tymi terminami odnosząc je do narodzin zapowiedzianego Mesjasza, by w oparciu o przekazy Ewangelistów ukazać historyczność faktu ${ }^{66}$ i udowodnić bezpodstawność oczekiwania Izraelitów na przyjście Tego, który już przyszedł. Łączy się to wreszcie z bardzo klarowną wizją powtórzoną za Justynem przez Afrykańczyka o dwóch przyjściach Chrystusa $^{67}$; pierwsze już się dokonało in humilitate, drugie zaś nastąpi tak, jak tego oczekują Izraelici in gloria ${ }^{68}$, lecz konsekwencje tego ostatniego będą diametralnie różne w stosunku do spodziewanych przez naród ongiś wybrany, którego miejsce zastąpili chrześcijanie. Dowodem na to jest fakt, iż po narodzeniu, śmierci i zmartwychwstaniu nie będzie już żadnej przepowiedni i proroctwa dotyczącego Jego przyjścia ${ }^{69}$. Opisując objawienie się ludzkości

${ }^{65}$ Por. Adversus Praxean 29, CCL 2, 1202-1203; zob. B. Studer, Dio Salvatore nei Padri della Chiesa, dz. cyt., 107.

${ }^{66}$ Por. Adversus Judaeos 8, 11 i 16, CCL 2, 1360-1361 i 1362: „Et superuixit idem Augustus, ex quo natus est Christus, annis xv, et erunt reliqua tempora annorum, [in diem nativitatis Christi, in annum Augusti xl primum, qui post mortem Cleopatrae xx et viii Augusto, efficiuntur anni ccccxxx et vii, menses vi] unde adimplentur lxii ebdomadae et dimidia, quae efficiunt annos ccccxxxvii, menses vi [in die natiuitatis Christi]... Post enim Augustum, qui superuixit post nativitatem Christi annis xv, efficiuntur: cui succedit tiberius Caesar et imperium habuit annis xxii, mensibus vii, diebus xxviii - huius quintodecimo anno imperii patitur Christus, annos habens quasi xxx, cum pateretur item caius Caesar, qui et Caligula, annis iii, mensibus viii, diebus xiii, tiberius claudius annis xii, mensibus viii, diebus xx, Nero annis xi, mensibus ix, diebus xiii, Galba mensibus vii, diebus vi”.

${ }^{67}$ Por. Apologeticum 21, 15, CCL 1, 125: „Duobus enim adventibus eius significatis, primo, qui iam expunctus est in humilitate condicionis humanae, secundo, qui concludendo saeculo imminet in sublimitate paternae potestatis acceptae <et $>$ divinitatis exsertae, primum non intellegendo secundum, quem manifestius praedicatum sperabant, unum existimaverunt".

68 Por. Adversus Judaeos 14, 1-2, CCL 2, 1391-1392: ,Duos dicimus Christi habitus a prophetis demonstratos, totidem adventus eius praenotatos: unum in humilitate, utique primum, cum tamquam ouis ad victimam deduci habebat et, tamquam agnus ante tondentem sine uoce sic non aperiens os, ne aspectu quidem honestus: adnuntiavimus enim, inquit, de illo: sicut puerulus, sicut radix in terra sitienti, et non erat ei species neque gloria; et vidimus eum, et non habebat speciem neque decorem, sed species eius inhonorata, deficiens citra filios hominum, homo in plaga positus et sciens ferre infirmitatem, scilicet ut positus a Patre in lapidem offensionis et <petram scandali> minoratus ab eo modicum citra angelos, vermem se pronuntians et non hominem, ignominia hominum et abiectio plebis”; De resurrectione 22, 2, CCL 2, 947: „In adventum, opinor, Christi vota nostra suspirant, in saeculi huius occasum, in transitum mundi quoque, ad diem domini magnum, diem irae et retributionis, diem ultimum et occultum nec ulli praeter Patri notum, et tamen signis atque portentis et concussionibus elementorum et conflictationibus nationum praenotatum".

69 Por. Adversus Judaeos 11, 10, CCL 2, 1382-1383: ,Itaque quoniam impletae prophetiae per adventum Iesu, id est per nativitatem, quam supra memoravimus, et passionem, quam evidenter ediximus, [propterea et Danihel signari visionem et prophetiam dicebat, quoniam Christus est 
zapowiedzianego w Piśmie św. Mesjasza, Tertulian posługuje się terminami venire in carnem, adventus, manifestari, Chrystus bowiem przyszedł w ciele ${ }^{70}$. Wyrażenia te świadczą pośrednio o tajemnicy wcielenia, podkreślają bowiem widzialny przez wielu naocznych świadków skutek tego wydarzenia bez precedensu. Przyjście Chrystusa (adventus) staje się bowiem dla człowieka kluczem do zmartwychwstania: „habes omnem substantiam hominis saluti destinatam, nec alio tempore quam in adventu Domini, qui clavis est resurrectionis"71.

Chrystus przyszedł na świat, aby objawić ludziom Ojca. Jego zatem wcielenie zapoczątkowało dzieło objawienia, pośrednio zatem mówiąc o tym Tertulian wskazuje na tę tajemnicę. Toteż dla wyrażenia tego aspektu objawienia Tertulian czasami, chociaż stosunkowo rzadko, używa czasowników manifestari i exhiberi (w różnych formach) oraz rzeczownika apparentia. Grecy opisując

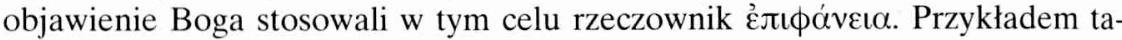
kiego zastosowania jest tekst z Adversus Praxean 27, 7 (CCL 2, 1199), związany z cytatami biblijnymi, szczególnie zaś z fragmentami pism św. Jana Apostoła:

,[Sermo]... quem si non capit transfigurari, consequens est ut sic caro factus intellegatur dum fit in carne et manifestatur et videtur et contrectatur per carnem, quia et cetera sic accipi exigunt, ${ }^{, 72}$.

Fragment $1 \mathrm{Tm} \mathrm{6,14}$ Tertulian przetłumaczył po łacinie jako in apparentiam domini Iesu Christi $^{73}$, natomiast 2 Tes 2,8 z przekładu Afrykańczyka znamy jako apparentia adventus $s u i^{74}$. Oczywiście łatwo zauważyć, iż same zacytowane teksty biblijne odnoszą się od objawienia się Chrystusa w czasach ostatecznych, dotyczy to zatem paruzji przed Sądem Ostatecznym a nie objawienia się w ciele jako skutku wcielenia.

Reasumując należy stwierdzić, iż Tertulian nie użył ani razu na określenie tajemnicy wcielenia łacińskiego rzeczownika incarnatio, który stał się terminem technicznym w teologii Kościoła Zachodniego. Opierając się na tekstach biblijnych stosował jednak całą gamę opisowych wyrażeń oraz tytułów mesjańskich Syna Bożego, które podkreślały jednoznacznie zarówno Jego Bóstwo, jak i prawdziwe Jego człowieczeństwo. Według Tertuliana wcielenie Syna Bożego stanowi fundament dzieła odkupienia ludzkości, albowiem bez wcielenia nie ma odkupienia. Terminologię zastosowaną przez Afrykańczyka schematycznie

signaculum omnium prophetarum, adimplens omnia quae retro erant de eo enuntiata; post enim adventum eius et passionem ipsius iam non visio neque prophetes".

${ }^{70}$ Por. De carne 24, 3, CCL 2, 916: ,Certe <cum dicit> qui negat Christum in carne venisse, hic antichristus est, nudam et absolutam et simplici nomine naturae suae pronuntians carnem, omnes disceptatores eius ferit".

71 De resurrectione mortuorum 47, 8, CCL 2, 987.

72 Adversus Praxean 27, 7, CCL 2, 1199.

73 Por. De resurrectione mortuorum 23, 11, CCL 2, 950.

${ }^{74}$ Por. tamże, 24, 19, CCL 2, 952. 
można podzielić na trzy grupy: formy opisujące ludzką naturę Chrystusa, Jego boskie pochodzenie, wydarzenie historyczne jako narodziny z Dziewicy Maryi, Jego wieczne istnienie w ciele oraz tajemnicę zbawienia w sensie globalnym. Pomimo faktu, iż Tertulian dosłownie interpretując niektóre teksty Pisma Świętego nie uchronił się przed poglądami heterodoksyjnymi takimi jak subordynacjanizm czy też przyznawanie dziewictwa Maryi tylko ante partum, to jednak jego wkład w definiowanie ortodoksyjnej teologii wcielenia jest niezaprzeczalny. Świadczyć o tym może awangardowa, jak na jego czasy, definicja o dwóch niezmieszanych naturach w Chrystusie, którą w sposób klarowny sformułował póżniej Sobór Chalcedoński.

\title{
LA PIÙ ANTICA TERMINOLOGIA LATINA DELLA TEOLOGIA DELL'INCARNAZIONE IN TERTULLIANO
}

\author{
(Riassunto)
}

La ricerca dei termini teologici, i quali sono stati adoperati da Tertulliano per descrivere il mistero dell'incarnazione, comprende tutti i testi che sono stati frutti della polemica dell'Apologista con tutti coloro che rientrarono nell'area della teologia eterodossa cristiana del II secolo. Alla base di quei testi si arriva ad individuare alcuni gruppi di termini che esprimono il fatto storico della nascita di Cristo dalla Vergine Maria ed anche gli aspetti teologici del mistero dell'incarnazione del Signore. Per Tertulliano il mistero dell'incarnazione è i fondamento di tutta l'opera della salvezza operata dal Signore. Adoperando molte espressioni eccetto il termine tecnico incarnatio Tertulliano pone in luce contro i doceti la vera umanità di Cristo (soprattutto a questo gruppo appartengono le espressioni: in carne, carneus, carnaliter, corpus Christi, corporatus, corporatio, incorporatio, homo, filius hominis, forma humana, habitus humanus, carnem fieri, carnem induere, accipere, sumere, suscipere, in carne venire ecc.), la sua vera divinità (anzitutto transfiguratus in carnem, indutus carnem, filius Dei, ed altri) ed anche contro i Giudei il fatto storico dalla sua nascita (nasci, generatus, genitus, ex Virgine Maria natus, ex Virginis carne e così via). Apologista sottolineando il fatto delle due parusie del Signore mette in evidenza il fatto che la prima avenne in humilitate, l'altra invece averrà in gloria. Anche questa osservazione è una conferma che il mistero dell'incarnazione è stato veramente avvenuto. Nonostante il subordinazionismo ed anche alcune difficoltà nell'accettare da parte di Tertulliano la verità della verginità di Maria ante partum, in partu e post partum le affermazioni dell'Apologista possono essere considerate ortodosse e in qualche modo anticipano la definizione del dogma formulato dal Concilio di Calcedonia soprattutto la sottolineatura del fatto che in Cristo si avverte duplicem statum, non confusum sed coniunctum in una persona, Deum et hominem Iesum. 